\title{
Determinants of Tax Compliance: A Review of Factors and Conceptualizations
}

\author{
Edward E. Marandu ${ }^{1}$, Christian J. Mbekomize ${ }^{1} \&$ Alexander N. Ifezue ${ }^{1}$ \\ ${ }^{1}$ Faculty of Business, University of Botswana, Gaborone, Botswana \\ Correspondence: Christian J. Mbekomize, Faculty of Business, University of Botswana, Private Bag UB 00701, \\ Gaborone, Botswana. Tel: 267-7144-9964. E-mail: mbekomizecj@ mopipi.ub.bw
}

Received: June 2, 2015

Accepted: June 18, 2015

Online Published:August 25, 2015

doi:10.5539/ijef.v7n9p207

URL: http://dx.doi.org/10.5539/ijef.v7n9p207

\begin{abstract}
This paper aims at providing a review of the factors that determine taxpayer compliance from a social marketing point of view. Data was obtained from 18 empirical studies published between 1985 and 2012 from across the globe. The findings made several revelations. First, too many and different explanatory factors have been proposed in the literature making comparison of findings across several studies difficult. Second, several researchers proceed without a theoretical framework to help guide the selection of independent factors. Since the use of theory enhances understanding of the major factors that affect a phenomenon, this deficiency has left the tax literature without a meaningful convergence on the key determinants. Third, aggregate analysis showed that attitudinal, normative and subjective control variables were on the overall good predictors of tax compliance. The findings suggest the following implications for research and policy action. First, it is recommended that future studies should seek to develop a few theory based set of relevant determinants of tax compliance that can yield accurate predictions. Second, tax policy makers are advised to desist from exclusive use of the conventional coercive methods (subjective control factors) normally used to compel tax compliance; instead they should take a balanced approach to tax enforcement that will also encourage voluntary compliance through change of attitudes and norms.
\end{abstract}

Keywords: tax compliance, theory of planned behaviour, attitude, norms, control

\section{Introduction}

\subsection{The Problem}

Many developing countries are now re-focusing on taxation to reduce over-dependency on aid or one source of revenue for development. In Botswana for example, in an effort to widen the tax base, the Income Tax Amendment Act of 2011 was passed (Benza, 2013). The Act makes it compulsory for every person with taxable income in excess of P36, 000 (about US $\$ 5,000$ ) per year to apply for a Taxpayer Identification Number (TIN) to enhance accountability for taxation. Botswana's efforts are consistent with those of the donor community. For example both OECD's Task Force on Tax and Development (2010) and the G-20(Keen, 2012), highlighted the importance of tax collection in developing countries. In addition the International Development Committee (2012) recommended that UK's aid program should increase its focus on supporting tax authorities.

Efforts by governments to generate tax revenues are hampered by widespread tax evasion among taxpayers in many countries. Tax revenues lost through tax evasion worldwide is estimated to be above US\$ 3.1 trillion which accounts for about $5.1 \%$ of world GDP. This translates to about $54.9 \%$ of healthcare spending lost to tax evasion. The impact of deliberate failure to pay tax to government is more severe in the developing countries. For example, $97.7 \%$ and $138.5 \%$ of health care budget is lost to tax evasion in African countries and South American countries respectively (Tax Justice Network, 2011). However, the desire to evade tax is prevalent in every country and this phenomenon has attracted numerous scholars to investigate the factors behind it.

Jackson and Milliron (1986) reviewed 46 tax compliance articles and identified eleven important factors that have been examined by researchers. These are tax system complexity, level of tax information services, withholding and information reporting and tax return preparer responsibilities and penalties. Others include probability of being audited, progressively and actual level of tax rates, penalties for non-compliance, age, gender, education and income. Subsequent to Jackson and Milliron study many more studies have been carried 
out and produced a myriad of factors that are more or less similar to Jackson and Milliron findings (Riahi-Belkaoui, 2004; Trivedi, Shehata and Mestelman, 2005; Saad, 2014; Fischer, Wartick, \& Mark, 1992; Hanno \& Violette, 1996; Chau \& Leung, 2009). There is, therefore, no shortage of literature on the subject of tax evasion or compliance. However, it appears that so far no study has assessed the collective adequacy of the factors employed in these studies.

\subsection{Objectives of the Study}

The broad objective of this study is to seek answer to the question why do some people pay taxes levied upon them while others do not? In more specific terms, the objectives of this paper are as follows:

1) To identify the factors that determine taxpayer compliance.

2) To assess the collective adequacy of the factors employed in various studies over time to explain tax compliance.

3) To conceptualize the various determinants of tax compliance into a meaningful whole.

The study is based on the underlying assumption that sustainable strategies for tax compliance should be oriented toward the use of persuasion rather than coercion. A heavy reliance on use of semi-military operations to prevent tax evasion may result in short term revenue increases but may prove to be difficult to sustain in the longer run and have considerable implications for politics in a democracy. This study is therefore being undertaken within the framework of marketing-related approaches in a nonprofit setting, often referred to as "social marketing". Basically, social marketing makes use of marketing techniques to improve social well-being by changing attitudes and behavior in regard to a specific product, idea or concept.

\subsection{Significance of Taxation}

Taxation is believed to be central to economic, social and political development. According to several authors a strong tax system can play three important roles in national development: revenue generation, lessen inequality (Cobham, 2005) and promote good governance. Now we turn to a brief discussion of each role.

First, revenue generation is the most obvious and direct role of taxation. Tax revenue are used to address immediate problems of human development such as outbreak of famine and emergency medical treatment and long term financing of public infrastructural services such as roads, airports, hospitals and schools. Income from aid and natural resources can substitute tax income, and might ensure that important development goals are reached. However, financing state spending through such sources contributes little to developing the institutional capacity of the state (Moore, 2004; Ross, 2001). In addition, compared to income from aid and natural resources, tax revenues based on a more robust domestic resource mobilization are relatively predictable (Bulír \& Hamann, 2007; Baine, no date).

Secondly, tax revenues provide income for a government which it may use to distribute as welfare transfers to reduce extreme poverty. Human poverty in middle-income countries, such as those in Latin America and the Caribbean, is more clearly the result of levels of income inequality than absolutely low income per se (Cobham, 2005). This implies that priority should be given to redistributive measures over an absolute need for tax revenues.

Finally, tax also plays a key role in building up institutions and democracy through making the state accountable to its taxpayers. History has shown that the formation of accountable and effective states has been closely bound up with the emergence of taxation systems (Baine, no date). A casual observation reveals that bad governance is often correlated with the state being independent of revenue from taxation of citizens and businesses. For example, in developing countries whose income derives mainly from sources other than taxation of their citizens, for instance from natural resources like oil and minerals, are generally characterized by bad governance and poor public institutions (Odd-Helge \& Rakner, 2009). Among the few exceptions are Botswana and Malaysia. Access to substantial foreign aid can also contribute to detaching the state from its citizens, and reducing the need for tax reforms (Bräutigam \& Knack, 2004).

\subsection{Significance of the Study}

The results of this study may be significant from both theoretical and practical standpoints. From a theoretical standpoint the study may help in developing a comprehensive theory of tax compliance. From a practical standpoint the findings may be of help for policy makers who will gain a better understanding of the factors that determine compliance for policy interventions. 


\section{Methodology}

\subsection{Scope of the Review}

The studies included in this review were identified by a systematic process. First a literature search was conducted on the University of Botswana Full Text Journals database for studies that spun the period between 1985 and 2012. Second, only papers that met the following criteria qualified for final inclusion in this review: (1) papers examining the determinants of tax compliance or evasion (2) papers that used tax compliance or evasion as the dependent variable (3) papers that are empirical based on data from taxpayers (individuals or organizations) as its subjects.

The authors identified 18 studies meeting the above criteria. Table 1 provides a list of authors of these studies as well as information on year of publication, theory or model used if any, the statistical method employed, sample size used and the country of data collection. Evidently, most of the data have been collected during the last 3 years, and from North America (6), Asia (4), Africa (3), Europe (2), Middle East (1) and world-wide (2). The fact that data have been collected from different countries reduces the comparability of the studies. Their findings can only be compared under the assumption that people/firms in different countries operate under fairly similar general tax conditions. Despite the diversity among the studies covered in this study, a comparison of their conceptualizations and findings is potentially fruitful for several reasons. First, a comparison of conceptualizations of the tax problem is valuable for improving future research. Second, a comparison of findings is apparently helpful from a practical tax management point of view.

\subsection{Analytical Approach}

In analyzing findings of the reviewed studies an approach to synthesizing a literature stream called meta-analysis was employed. Meta-analysis is a set of statistical techniques for summarizing the results of several studies into a single estimate of the effect. Since the tax compliance studies reported here are characterized by heterogeneity of measurement and analytical approaches, only a weak form of meta-analysis, called the vote counting technique, is applicable(Hedges \& Olkin, 1980). Essentially, the vote-counting approach summarizes, for each independent factor, the number of studies that report a positive effect, a negative effect, or a non-significant effect on tax compliance (Zou, 1998).

Assuming that a positive true effect of a factor on compliance would result in a high probability of several empirical studies reporting a positive effect, the null hypothesis of "no effect" should be rejected if the number of positive findings is larger than a critical value, which depends on the total number of studies. For example, the critical value is four for 10 to 15 studies, five for 20 studies, and six for 30 studies(Hedges \& Olkin, 1980). Hence, the vote-counting technique offers a simple and yet clear picture to readers with regard to the likely sign of the true effect of a factor. Using the vote counting method, an attempt was then made to summarize findings of the reviewed studies, using the Theory of Planned Behaviour (TPB) as the conceptual framework.

Table 1. Tax compliance/evasion studies reviewed

\begin{tabular}{|c|c|c|c|c|c|c|}
\hline & Author(s) & Theory/Model & $\begin{array}{c}\text { Year of } \\
\text { Publication }\end{array}$ & Statistical Method & Sample Size & $\begin{array}{l}\text { Country of Data } \\
\text { Collection }\end{array}$ \\
\hline 1 & Damayanti & $\begin{array}{c}\text { Theory of Planned } \\
\text { Behaviour }\end{array}$ & 2012 & Regression analysis & $\begin{array}{l}114 \text { individual } \\
\text { taxpayers }\end{array}$ & Indonesia. \\
\hline 2 & $\begin{array}{l}\text { Maciejovsky, } \\
\text { Schwarzenberger, \& Kirchler }\end{array}$ & None & 2012 & $\begin{array}{c}\text { Analysis of Variance } \\
\text { ANOVA and (Mann- } \\
\text { Whitney test }\end{array}$ & $\begin{array}{c}253 \text { individual } \\
\text { taxpayers and } 463 \\
\text { students }\end{array}$ & UK \\
\hline 3 & Benk, Çakmak, \& Budak & $\begin{array}{c}\text { Theory of Planned } \\
\text { Behavior }\end{array}$ & 2011 & $\begin{array}{c}\text { Factor Analysis \& Multiple } \\
\text { regression }\end{array}$ & $\begin{array}{l}369 \text { individual } \\
\text { taxpayers }\end{array}$ & Turkey \\
\hline 4 & Palil \& Mustapha & None & 2011 & Multiple regressions & $\begin{array}{l}1073 \text { individual } \\
\text { taxpayers }\end{array}$ & Malaysia \\
\hline 5 & Hai \& See & $\begin{array}{l}\text { Extension of Theory } \\
\text { of Reasoned Action }\end{array}$ & 2011 & Multiple regressions & $\begin{array}{l}196 \text { individual } \\
\text { taxpayers }\end{array}$ & Malaysia \\
\hline 6 & $\begin{array}{l}\text { Bame-Aldred, Cullen, } \\
\text { Martin, \& Parboteeah }\end{array}$ & $\begin{array}{l}\text { Institutional Anomie } \\
\text { Theory }\end{array}$ & 2011 & $\begin{array}{l}\text { Hierarchical Generalized } \\
\text { Linear Modeling (HGLM) }\end{array}$ & 3331 firms & World-wide \\
\hline 7 & Ahangar, Bandpey, \& Rokny & None & 2011 & Descriptive Method & I44 Tax Specialists & Iran \\
\hline 8 & Fagbemi, Uadiale, \& Noah & None & 2010 & $\begin{array}{c}\text { Descriptive \& Inferential } \\
\text { statistics }\end{array}$ & 36 Tax Officers & Nigeria \\
\hline
\end{tabular}




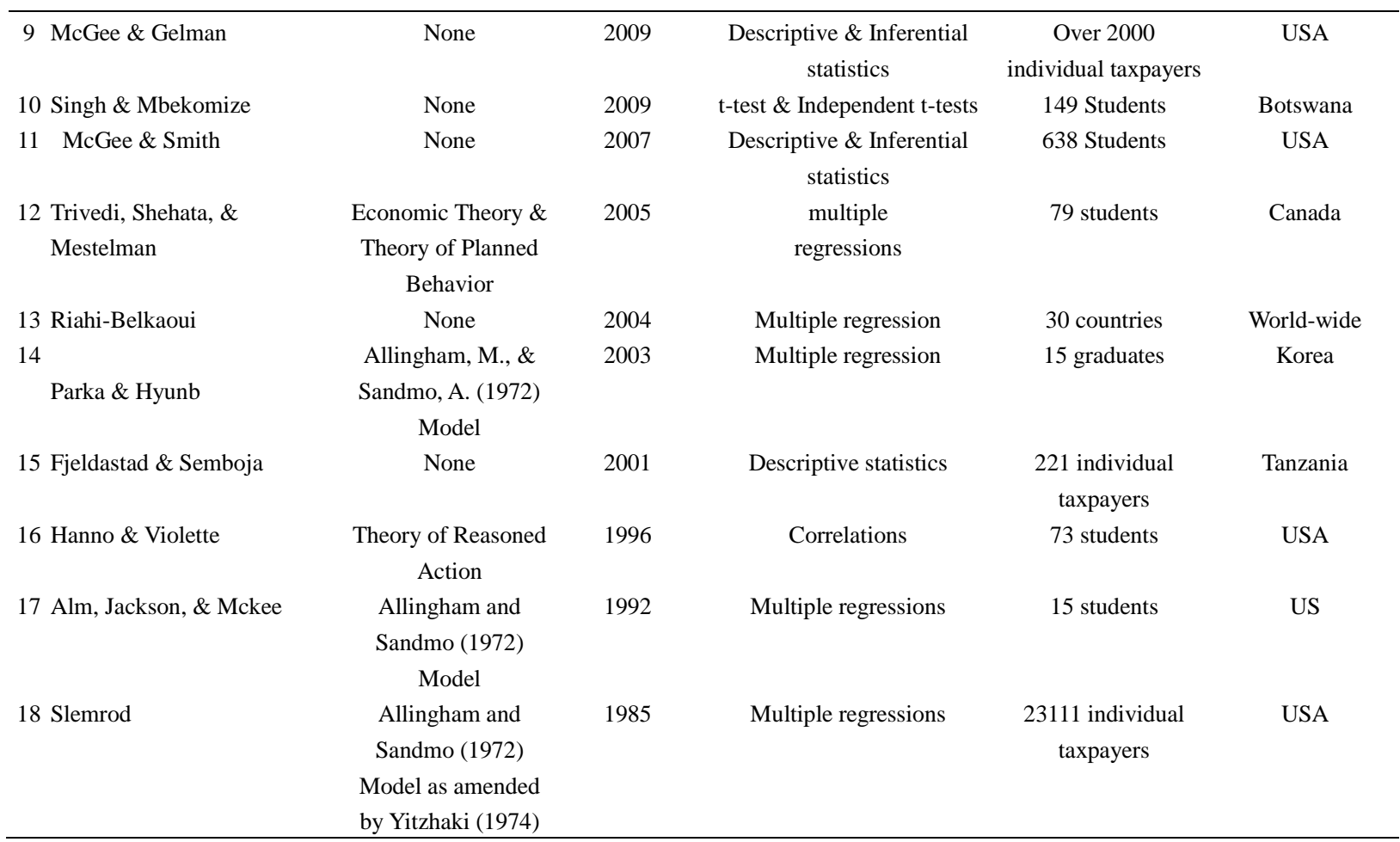

\section{Findings from the Literature Reviewed}

\subsection{Independent Factors}

The first and obvious problem of the tax compliance studies reviewed here is the myriad of factors hypothesized to influence tax compliance. In fact, the number of different operationalized variables in the 18 reviewed studies was no less than 70 . In several cases an operationalized variable was unique to a single study. This made it difficult to compare results of the different studies because of lack of commonality in nomenclature among the variables used.

Table 2. Variables used and association with tax compliance

\begin{tabular}{|c|c|c|c|c|}
\hline \multirow[b]{2}{*}{ Variable } & \multicolumn{3}{|c|}{ Number of findings which displayed: } & \multirow{3}{*}{$\begin{array}{c}\text { Totals } \\
29(100 \%)\end{array}$} \\
\hline & $\begin{array}{c}\text { Positive } \\
\text { association }\end{array}$ & $\begin{array}{c}\text { Negative } \\
\text { association }\end{array}$ & $\begin{array}{c}\text { No } \\
\text { association }\end{array}$ & \\
\hline ATTITUDE & $21(72 \%)$ & $7(24 \%)$ & $1(3 \%)$ & \\
\hline 1. Summative Attitude & 3 & & & 3 \\
\hline 2. Perception of equity and fairness & 4 & 1 & & 5 \\
\hline 3. Affective priming (Emotions) & & 1 & & 1 \\
\hline 4. Cognitive priming (ease with which to retrieve tax-related info & 1 & & & 1 \\
\hline 5. Perception of provision of public good & 3 & & 1 & 4 \\
\hline 6. Tax knowledge/tax education & 2 & & & 2 \\
\hline 7. Expected costs of non-compliance & 1 & & & 1 \\
\hline 8. Ethics & 2 & & & 2 \\
\hline 9. Unfair treatment of Citizens & & 3 & & 3 \\
\hline 10. Religious Observance & 1 & & & 1 \\
\hline 11. Freedom of Speech & 1 & & & 1 \\
\hline 12. Freedom of Worship (Tolerance) & 1 & & & 1 \\
\hline 13. Individualism & & 1 & & 1 \\
\hline 14. Achievement orientation & 1 & & & 1 \\
\hline 15. Assertiveness & 1 & & & 1 \\
\hline 16. Perceived tax burden & & 1 & & 1 \\
\hline
\end{tabular}




\begin{tabular}{|c|c|c|c|c|}
\hline SUBJECTIVE NORMS & $7(78 \%)$ & $2(22 \%)$ & & $9(100 \%)$ \\
\hline 1. Summative Subjective Norms & 3 & & & 3 \\
\hline 2. Normative expectations & 1 & & & 1 \\
\hline 3. Referral group & & 1 & & 1 \\
\hline 4. High Moral norms & 1 & & & 1 \\
\hline 5. Known number of tax evaders & & 1 & & 1 \\
\hline 6. Unapproved tax preparer influence & 1 & & & 1 \\
\hline 7. Unapproved account preparer influence & 1 & & & 1 \\
\hline PERCEIVED BEHAVIORAL CONTROL & $25(49 \%)$ & $21(41 \%)$ & $5(10 \%)$ & $51(100 \%)$ \\
\hline 1. Summative Perceived Behavioral Control & 2 & & & 2 \\
\hline 2. Legal sanctions (penalties and fines) & 5 & 1 & 1 & 7 \\
\hline 3. Probability of being audited & 5 & 1 & & 6 \\
\hline 4. The role of tax authority & 1 & & & 1 \\
\hline 5. Corrupt Government & & 2 & & 2 \\
\hline 6. Level of Education & 1 & & & 1 \\
\hline 7. Rule of law & 1 & & & 1 \\
\hline 8. Corporate tax burden & & 1 & & 1 \\
\hline 9. Gross National Product (GNP) & & & 1 & 1 \\
\hline 10. Firm size & 1 & & & 1 \\
\hline 11. Individual ownership & & & 1 & 1 \\
\hline 12. Industry: agriculture & & & 1 & 1 \\
\hline 13. Industry: construction & & 1 & & 1 \\
\hline 14. Effective competition laws & 1 & & & 1 \\
\hline 15. Economic freedom & 1 & & & 1 \\
\hline 16. Importance of equity market & 1 & & & 1 \\
\hline 17. Poor working conditions of tax agent & & 1 & & 1 \\
\hline 18. Weakness of tax information system & & 1 & & 1 \\
\hline 19. Accumulation of tax cases & & 1 & & 1 \\
\hline 20. Complexity of tax law & & 1 & & 1 \\
\hline 21. Lack of proper tax culture & & 1 & & 1 \\
\hline 22. Poor enforcement of direct tax law & & 1 & & 1 \\
\hline 23. Lack of systematic crimes prosecution & & 1 & & 1 \\
\hline 24. Corruption of tax agents & & 1 & & 1 \\
\hline 25. Vast and various exemptions & & 1 & & 1 \\
\hline 26. Income/ability to pay & 4 & 3 & 1 & 8 \\
\hline 27. Tax rate & & 3 & & 3 \\
\hline 28. Humane orientation & 1 & & & 1 \\
\hline 29. Affiliation to current government & 1 & & & 1 \\
\hline OTHERS: & $5(83 \%)$ & $1(17 \%)$ & & $6(100 \%)$ \\
\hline 1. Marital status/Married & & 1 & & 1 \\
\hline 2. Age & 3 & & & 3 \\
\hline 3. Gender (Women more likely to be tax compliant) & 2 & & & 2 \\
\hline
\end{tabular}

\subsection{Theoretical Framework}

The second problem and related to the one above is the lack of an underlying theoretical framework that cuts across the various studies to help guide the selection of independent factors. As a matter of fact half of the studies reviewed did not make reference to any conceptual or theoretical reasoning in developing the research questions or hypotheses. The use of theory enhances the understanding of the major factors that affect tax compliance which is not easy with the latter approach. The lack of a conceptual framework results in knowledge on tax compliance behavior that exists in pieces which do not come together into a coherent package of received wisdom. There is a need for researchers to be more mindful of the usefulness of theory when conducting tax compliance research.

In order to integrate the various factors, the operationalized factors must be categorized into some more general concepts using some theory. To achieve this, a brief scan of the literature was undertaken in order to identify a suitable theory for integrating the various factors. 


\subsection{Theories of Tax Compliance}

Our review of the 18 papers suggests that several theories of behavior, borrowed from economics and the psychological sciences, can be useful in classifying the variables in this analysis. These include:

- Allingham and Sandmo (1972) Model,

- Institutional Anomie Theory, and

- The Theory of Planned Behavior.

3.3.1 Allingham and Sandmo (1972) Model

In 1968 Nobel laureate Becker theorized the economics of crime on the basis of which Allingham and Sandmo (1972) produced an economic model of tax compliance. The model was seminal for it was followed by a large number of contributions to the literature which extended the original model in a number of directions.

In the model, the taxpayer is assumed to have an income I and must choose the amount to declare to the tax agency (Alm, Jackson, \& McKee, 1992). Declared income D is taxed at the rate $t$; undeclared income is not taxed, but the taxpayer will face a probability of detection $\mathrm{p}$ at which point a fine $\mathrm{f}$ will be imposed for cheating. The taxpayer has the choice between two strategies: (1) He may declare his true income or (2) he may declare less than his true income. If he chooses the latter strategy his payoff will depend on whether or not he is investigated by the tax authorities. If he is not, he is clearly better off than under strategy one. If he is investigated, he is worse off as the audit may lead to penalties. Thus the taxpayer chooses D to maximize the expected utility of the evasion gamble.

This framework suggests that declared income depends upon $\mathrm{I}, \mathrm{p}, \mathrm{f}$ and $\mathrm{t}$ :

$$
D=f(I, p, f, t)
$$

This model shows that declared income $\mathrm{D}$ varies directly with income, the probability of detection (audit rate) and the penalty (fine rate), but inversely with the tax rate.

There are however other factors that affect compliance decision; while government "taketh away, it also giveth back" (Alm, Jackson, \& McKee, 1992) and this surely exerts influence on compliance or evasion. The declared income D may be modified to reflect individual's receipt of Government expenditures $\mathrm{G}$ as follows:

$$
D=f(I, p, f, t, G)
$$

Thus compliance is also directly related to individual's perceived benefits from public good funded by their tax payments.

This economics-of-crime approach and its extensions is based on the assumption that an individual pays taxes only because of the economic consequences of the evasion gamble and because they fear detection and punishment. However, it is clear that compliance cannot be explained entirely by such purely economic considerations and level of enforcement. In fact it has been shown that the percentage of income tax returns that are subject to a thorough tax audit is generally quite small in most countries, almost always well less than 1 percent of all returns (Alm, 2012). Therefore, although the Allingham and Sandmo Model of 1972 is elegant in its simplicity, many potentially relevant noneconomic factors are necessarily omitted.

\subsubsection{Institutional Anomie Theory (IAT)}

Anomie is a sociological theory that holds that individuals make decisions based on socialized values, which separately may be contradictory but together, balances each other out, producing behavior considered "normal" by society. When one holds an imbalanced set of values, decisions made on that set may produce deviant behavior, such as everyday crime (Itashiki, 2011). Specifically, the most recent rendition of anomie theory, institutional anomie theory (Messner \& Rosenfeld, 2001) appears readily adaptable for examining the relationship between cultural values and tax evasion behaviors (Riahi-Belkaoui \& Picur, 2000). Institutional Anomie Theory highlights four theoretically derived sets of national cultural dimensions likely to promote or suppress tax evasion. They include individualism, achievement orientation, assertiveness and humane orientation.

Individualistic cultural values set the stage for behaviors that emphasize the pursuit of firm self-interest, largely neglecting concern for ethical consequences. According to IAT, individualistic cultural values encourage firm's decision makers to choose goal achievement beyond concerns for the ethical or legal means to achieve goals (Bame-Aldred, Cullen, Martin, \& Parboteeah, 2011). Thus, in such societies, firms more willingly deviate from accepted norms and evade taxes. On the contrary, collectivist cultures favor allegiance to the greater collective rooted in the notion that societal members are interdependent (Triandis, 1995) and, as such, should deter 
individual gains at the expense of the collective. This suggests that individualistic cultural values should inflate temptations for firms to evade taxes.

\subsubsection{Theory of Planned Behavior}

The Theory of Planned Behavior (Figure 1) was proposed by Ajzen (1985) as an extension of the Theory of Reasoned Action, which had been proposed a decade earlier, by (Fishbein \& Ajzen, 1975). According to the Theory of Reasoned Action, people are more likely to do a behavior if they evaluate the suggested behavior as having positive results (attitude) and if they think their significant others want them to perform the behavior (subjective norm). A high correlation of attitudes and subjective norms to behavior has been confirmed in many studies (Sheppard, Hartwick, \& Warshaw, 1988). However, the same authors have raised a counterargument against the high relationship between attitude, subjective norms and behavior. They argued that because of circumstantial limitations, attitude and subjective norms do not always lead to behavior. To improve on the predictive power of the Theory of Reasoned Action Ajzen added a new component "perceived behavioral control" to help account for behaviors that arise where an individual's control over the behavior is incomplete. By this, he extended the Theory of Reasoned Action to include the role of non-volition in predicting behavior. The extended version is called the Theory of Planned Behavior.

Behavioral, Normative and Control beliefs: In addition, the three predictors are determined as follows: Attitude is a function of behavioral belief or salient information, which is the perceived likelihood that performing the particular behavior will lead to certain consequences, weighted by the extent to which these consequences are valued. Subjective norm is a function of normative belief which is the perceived pressure from specified referents to perform the target behavior, weighted by the motivation to comply with the people one cares about. Perceived behavioral control is determined by control belief which is the perceived access to the necessary resources and opportunities to perform a behavior successfully, weighted by the perceived power or effect of the particular control factor.

Intention and Behavior: Intention is the cognitive representation of a person's readiness to perform a given behavior and is considered to be the immediate antecedent of behavior. Behavior is the translation of intention to action.

The main hypothesis of the Theory of Planned Behavior is that there is one immediate determinant of behavior, namely the person's intention to perform or not perform it. This intention is itself, in turn, viewed as determined by three things: attitude, subjective norms and subjective control toward the specific behavior. More specifically, the Theory of Planned Behavior attempts to provide an account of the way in which attitude, subjective norms, subjective control and intentions combine to predict behavior.

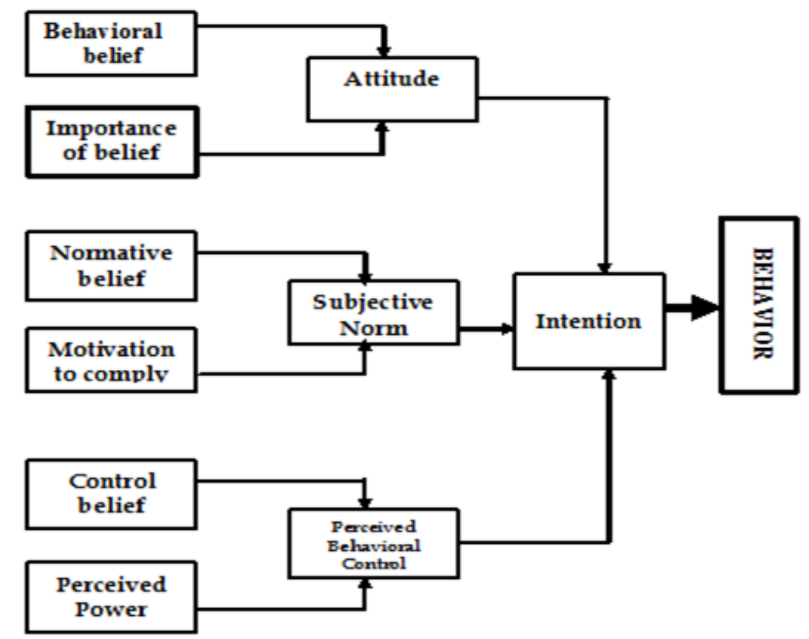

Figure 1. Theory of planned behavior

\subsubsection{Synthesis}

The various tax compliance theories presented above should be treated as complementary rather than competing with each other. Each emphasizes different aspects of the various determinants of compliance. Each aspect 
contributes towards a better understanding of compliance or evasion behavior. No single theory has been invented which incorporates all predictors of tax compliance.

In addition, the various theories may not be as empirically distinct as they appear by their names. They are called by different names, but in reality they overlap and use many common explanatory variables. For example the use of economic considerations and level of enforcement which is used in the Allingham and Sandmo Model is to some extent similar to the concept of Subjective Control in the TPB and the whole of Institutional Anomie Theory is similar to the concept of Subjective Norms in the TPB. Therefore the TPB appears to be the most comprehensive of them all. It integrates, though not completely, ideas from the other two models and introduces new ones. The model therefore, provides a useful starting point in classifying factors that influence tax compliance/evasion.

\subsection{Classification of the Factors}

The Theory of Planned Behavior was used to help classify the various determinants of tax compliance. Using the TPB, tax compliance is conceptualized as a function of three broad factors: attitude, subjective norms and subjective control. This classification coincides very well with the approach taken in five of the 18 studies reviewed in this study (Damayanti, 2012; Benk, Çakmak, \& Budak, 2011; Hai \& See, 2011; Trivedi, Shehata, \& Mestelman, 2005; Hanno \& Violette, 1996).

As mentioned earlier, initially there were 70 operationalized factors. Fifteen of these were so similar to an earlier listed factor and were merged together, thus leaving55 somewhat distinct factors. In reviewing the studies the 55 operationalized factors were classified into Attitude (16 factors), Subjective Norm (7 factors) or Subjective Control (29 factors). Three factors which could not fit into any of these three categories were placed in a fourth catchall category called "Others". The main finding here is that the component that received most attention in terms of variable inclusion is Subjective Control with about 53\% of the factors; Attitude with about $29 \%$ of the factors is a distant second; Subjective Norm with about $13 \%$ of the factors is measured by much fewer operational factors. This suggests that subjective control is a construct with relatively many operational dimensions, followed by attitude and subjective norm has relatively few operational dimensions. The findings also suggest that about 5\% of the factors used in empirical studies cannot be classified into the broad factors that constitute the Theory of Planned Behavior.

\subsection{Adequacy of the Factors Used in Studies Reviewed}

Applying the TPB would ideally imply that an empirical study of tax compliance should include at least the factors that comprise the three variable groups: namely attitude, subjective norms and subjective control. However, the typical picture from the reviewed studies is that 13 of the 18 studies included factors from only one of the three variable groups. This suggests that most of the reviewed studies suffer from specification errors by not being comprehensive enough in their inclusion of factors deemed to influence tax compliance.

\subsection{Impact of Attitude, Norms and Control}

Based on the vote-counting method the results on impact of Attitude, Norms and Control are presented in Table 2. The tabulation contains, for each independent factor, the total number of studies that found a positive effect, a negative effect, or no effect on tax compliance.

\subsubsection{Did Attitude Matter in Determining Tax Compliance?}

The answer to this question was found by both individual and aggregate analyses of the 16 attitudinal factors identified earlier in this study. The individual analysis involved counting how many times each independent variable was found to be associated with tax compliance, whether positively, negatively or no association, taking each variable one at a time. Two variables displayed mixed findings. The first was "perception of equity and fairness" which was examined in five studies: four of them reflected positive relationships and one reflected a negative relationship with tax compliance. It is apparent that the variable "Perception of equity and fairness" is more likely to be positively associated with tax compliance. The second variable was "perception of provision of public good" which was employed in four studies: three of them displayed positive associations and one displayed no association with tax compliance. These results suggest that this variable is more likely to be positively associated with tax compliance. The rest of the attitudinal variables displayed either positive or negative association with tax compliance; none displayed mixed findings (positive in one study, negative in another). It is concluded that all the 16 attitudinal variables used in the study contributed either positively or negatively to explaining tax compliance behavior.

The aggregate analysis involved adding together the number of findings that were positive, those that were negative and the ones that displayed no association with tax compliance. The aim was to provide a rough 
indicator on how good the attitudinal factors used in the reviewed studies were in predicting tax compliance. A variable was assumed to be a good predictor if it displayed a relationship (positive or negative) with tax compliance. The results show that of the 29 attitudinal findings produced by the study, 21 findings displayed positive associations and 7displayed negative associations; meaning that the variables used produced 28 (almost all) impactful findings. These results suggest that the attitudinal variables employed in the studies were appropriate or good predictors of tax compliance.

\subsubsection{Did Subjective Norms Matter in Determining Tax Compliance?}

In the same fashion as attitude the answer to this question was found by both individual and aggregate analyses of the 7 normative factors identified earlier in this study. Generally the findings are similar to those on attitude. The normative variables displayed either positive or negative association with tax compliance; none displayed no association or mixed findings. Perhaps the interesting finding to note is the negative association between compliance and the variable "Known number of tax evaders". This implies that if an individual knows that others are evading taxes he or she is motivated to do the same.

The results of the aggregate analysis show that of the 9 normative findings produced by the study, 7 findings displayed positive associations and 2 displayed negative associations; meaning that using our yardstick, all of the normative variables were good predictors of tax compliance.

\subsubsection{Did Behavioral Control Matter in Determining Tax Compliance?}

Once again the answer to this question was found by both individual and aggregate analyses of the 29 subjective control factors identified earlier in this study. The following findings emerge from the individual analysis of the variables: First, three of the variables from three different studies showed no association with tax compliance/evasion and these are: "Gross National Products", "Individual ownership" and "Industry: agriculture". Second, three of the variables displayed mixed findings. These are "Legal sanctions-penalties and fines" which showed positive relationship in five studies, negative association in one study and no association in another, the "probability of being audited" which also showed positive relationship in five studies and negative association in one study. The trend of both variables was clearly towards positive association with tax compliance. The other variable "Income/ability to pay" reflected positive relationship in four studies, negative association in three studies and no association in one study-in this variable the trend is not clear and it is safer to conclude no association. Third, the remaining 23 subjective control variables were associated with compliance either positively or negatively, with no mixed results.

The aggregate analysis showed that of the 51 behavioral control findings produced by the study, 25 findings displayed positive associations, 21 displayed negative associations, and 5 displayed no significant associations. Applying the criteria established earlier that a variable is considered to be a good predictor if it displayed impactful relationship (positive or negative) with tax compliance, then the subjective control variables used in the studies were good for they produced 46 impactful findings of the 51 findings under subjective control.

\subsubsection{Effect of Other Factors}

Three of the factors employed in the studies could not be classified under any of the three main constructs of the TPB that is, attitude, subjective norms and subjective control. These were demographic factors, namely gender (females more compliant), age (positive association) and marital status (unmarried more compliant). This suggests that tax compliance behavior determination is a complex process.

\section{Conclusions, Future Research and Implications}

\subsection{Conclusions and Future Research}

1) There is evidence from the literature reviewed that although tax compliance has been the subject of considerable empirical research, however, no homogeneity in the determinants of tax compliance has been achieved. There are too many and different explanatory factors that have been proposed in the literature as determinants of tax compliance. The problem with this situation is that when undertaking an empirical study one would be faced with choosing a set of predictor variables from what is a very large set of candidate predictors. It is therefore recommended that future research need to develop a meaningful set of few predictors that yield accurate predictions.

2) The second conclusion and related to the one above is that some studies on tax compliance proceed without a theoretical framework to help guide the selection of independent factors. In some of the studies that use some theory, the theories are not comprehensive. For example the Allingham and Sandmo Model focuses on economic factors while the Institutional Anomie Theory focuses on cultural factors. Only the Theory of 
Planned behavior embraces a wider spectrum of variables involving attitudes, social norms and behavioral control. It follows that many of the studies on tax compliance reviewed in this study that did not use the TPB may be misleading because of under-specification of the causal factors.

3) Nevertheless the literature suggests that tax compliance research has made a big step forward in recent years by adopting the more comprehensive TPB. This development has significantly strengthened the theoretical foundation of research on tax compliance. Now, researchers would be able to build their studies upon some fairly comprehensive theoretical foundation.

4) Despite this positive progress in theory development, the tax compliance literature is still plagued by several problems. The TPB is a general theory, not specifically developed for tax compliance behaviour and hence it may fail to capture behavioural factors that are unique to tax compliance.In fact it is a requirement by the TPB that investigators should interview a sample of the group under investigation to determine the salient attitudes, identify significant others and subjective control factors that are relevant to the study group or research issue in question. Thus future researchers are encouraged to develop tax specific TPB questionnaire that captures attitudinal, normative and control factors that are relevant to tax compliance and follow it with empirical studies. A potentially fruitful research direction is to use the independent factors revealed in this review, as well as those of other reviewers to classify the variables, using the conceptual domain suggested by the TPB; develop sound schemes to measure the factors, and assess the reliability, validity, and cross-cultural consistency of the measures. Although the TPB is considered comprehensive, the review findings suggest that it is still not comprehensive enough to capture all key determinants of tax compliance. For example, demographic factors which were found in empirical studies to be good predictors of tax compliance could not be classified to fit into any of the components of the theory. Therefore future researchers may consider developing an extended or modified version of the Theory of Planned Behavior that is specific to tax compliance behavior. Since tax compliance appears to be a complex behavioral process, a potentially useful research effort might be to focus attention on classifying the various causal factors into different categories such as antecedent, moderator, mediator and proximate determinants of tax compliance within the general framework of the Theory of Planned Behavior.

5) The reader may have noticed that the vote counting method could not be used properly as the variables discussed in this review were of little commonality and most were unique to each study. This made it difficult to compare results of the different studies because of lack of commonality among the variables used. Despite this difficulty, aggregate analysis showed that on the whole the attitudinal, normative and subjective control variables used in most of the studies were good predictors of tax compliance. Therefore future researchers are advised to focus efforts in developing common key tax terminologies and variables which can be used to compare findings from different studies. With a reasonable number of independent variables and possibly common statistical analyses, cumulative knowledge can be more readily summarized by more rigorous meta-analyses in the future.

6) One third (six) of the reviewed studies used students as respondents. Future researchers are advised to use actual taxpayers rather than students who may not adequately understand and display actual behavior of tax compliance.

\subsection{Implications for Tax Administration Authorities}

On the basis of the conclusions one major implication for tax administration emerges. The findings from this review imply that tax compliance is a wide and complex phenomenon. To be effective in inducing and enforcing tax compliance, public policy makers need to use a combination of persuasive methods (changing attitudes and norms) as well as the conventional coercive methods (subjective control). The point is that, there is a need to direct attention on changing attitude of individual taxpayers as well as that of significant others (family members, friends, colleagues and opinion leaders-highly visible, respected people) whose influence is important in encouraging or discourage tax compliance. In this way promotion of taxpayer compliance could be extended to enlisting influential members of the community, households, friends and colleagues to disseminate tax compliance messages. If the process gains a critical mass, one may expect norms to change which will in turn influence behavioral patterns. Thus tax authorities are advised to engage in a balanced approach to tax enforcement that will encourage voluntary compliance as well as use of the conventional coercive apparatus of the state to compel tax compliance.

For example government may develop an education program that has three themes with a view of building a culture of tax compliance. The first theme can be to create the perception that tax revenues are being utilized properly (attitude). The second theme can be a program in mass media showing examples of businessmen paying 
taxes and how these taxes have been used to enhance development for the country and create employment. They should be presented as responsible citizens, and in some cases as heroes. Finally such program may portray tax evaders as saboteurs of the national economic, social and cultural development who deserve to be ridiculed by society and punished.

\section{References}

Ahangar, R., Bandpey, H., \& Rokny, H. (2011). An Investigation into the determinat of effective factors on tax evasion (Empirical study of Iran Tax Affairs Organisation). American Journal of Scientific Reserach, 99-113.

Ajzen, I. (1985). From intentions to actions: A theory of planned behavior. Berlin: Heidelber, New York: Springer-Verlag.

Alm, J., Jackson, B., \& Mckee, M. (1992). Estimating the determinats of taxpayer compliance with experimental data. National Tax Journal, 45(1), 107-114.

Baine, M. (n. d.). Role of Taxation in State building and Good governance-The Rwandan experience. Norad's Annual Conference on Poverty and Development. Oslo, Norway.

Bame-Aldred, C., Cullen, J., Martin, K., \& Parboteeah, K. (2011). National Culture and firm-level tax evasion. Journal of Business Reserach, 1-7.

Benk, S., Çakmak, A., \& Budak, T. (2011). An Investigation of Tax Compliance Intentions: A Theory of Planned Behaviour Approach. European Journal of Economics, Finance and Administrative Sciences, 28.

Benza, B. (2013, July 11). Net closes in on tax evaders. Mmegi Online.

Bräutigam, D., \& Knack, S. (2004). Aid dependence and governance in Africa. Economic Development and Cultural Change, (January).

Chau, K. K., \& Leung, P. (2009). A critical review of Fischer tax compliance model: A research synthesis. Journal of Accounting and Taxation, 1(2), 34-40.

Chetty, S. K., \& Hamilton, R. T. (1993). Firm-level determinants of export performance: A metaanalysis. International Marketing Review, 10(3), 26-34. http://dx.doi.org/10.1108/02651339310040643

Cobham, A. (2005). Taxation policy and development. Oxford: The Oxford Council on Good Governance.

Damayanti, T. (2012). Changes on Indonesia Tax Culture, Is there a way? Studies through theory of planned behavior. Journal of Arts, Science \& Commerce, 4(1), 8-15.

Fagbemi, T., Uadiale, O., \& Noah, A. (2010). The Ethics of Tax Evasion: Perpetual Evidence from Nigeria. European Journal of Social Science, 17(3), 360-371.

Fischer, C. M., Wartick, M., \& Mark, M. (1992). Detection Probability and Taxpayer Compliance: A Review of the Literature. Journal of Accounting Literature, 11, 1-46.

Fishbein, M., \& Ajzen, I. (1975). Belief, attitude, intention, and behavior: An introduction to theory and research. Reading, MA: Addison-Wesley.

Fjeldastad, O., \& Semboja, J. (2001). Why people pay taxes: The Case of the development Levy in Tanzania. World Development, 29(12), 2059-2074. http://dx.doi.org/10.1016/S0305-750X(01)00081-X

Hai, O., \& See, L. (2011). Behavioral Intention of Tax Non-Compliance among sole-proprietors in Malaysia. Centre for Promoting Ideas, 142-152.

Hanno, D., \& Violette, G. (1996). An Analysis of Moral and Social Influences on Taxpayer Behavior. Behavioral Reserach in Accounting, 8(Supplement), 57-79.

Hedges, L. V., \& Olkin, I. (1980). Vote-counting methods in research synthesis. Psychological Bulletin, 88(2), 359-369. http://dx.doi.org/10.1037/0033-2909.88.2.359

Itashiki, M. (2011). Explaining "everyday crime": a test of anomie amd relative deprivation theory (Unpublished doctor of philosophy dissertation). University of North Texas.

Jackson, B. R., \& Milliron, C. V. (1986). Tax compliance research: Findings, problems and prospects. Journal of Accounting Literature, 125-165.

Keen, M. (2012). Taxation and Development-Again. New York: International Monetary Fund, Working Paper $/ 12 / 220$. 
Maciejovsky, B., Schwarzenberger, H., \& Kirchler, E. (2012). Rationality Versus Emotions: The Case of Tax

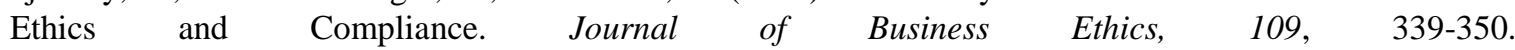
http://dx.doi.org/10.1007/s10551-011-1132-2

McGee, R. W., \& Smith, S. R. (2007, January). Ethics, Tax Evasion, Gender and Age: An Empirical Study of Utah Opinion. Retrieved from http://papers.ssrn.com/sol3/papers.cfm?abstract_id=955973

McGee, R., \& Gelman, W. (2009). Opinions on the ethics of tax evasion: A Comparartive study of the USA and six Latin American Countries. Akron Tax Journal, 24, 69-91.

Messner, S., \& Rosenfeld, R. (2001). Crime and the American dream. Belmont, CA: Wadsworth.

Moore, M. (2004). Revenues, state formation, and the quality of governance in developing countries. International Political Science Review, 25(3), 217-319. http://dx.doi.org/10.1177/0192512104043018

Odd-Helge, F., \& Rakner, L. (2009). The importance of taxes for development. Bergen, Norway: Chr. Michelsen Institute.

Palil, M., \& Mustapha, A. (2011). Determinants of Tax Compliance in asia: A case of Malaysia. European Journal of Social Sciences, 24(1), 7-32.

Parka, C. G., \& Hyunb, J. K. (2003). Examining the determinants of tax compliance by experimental data: A case of Korea. Journal of Policy Modeling, 25(8), 673-684. http://dx.doi.org/10.1016/S0161-8938(03)00075-9

Riahi-Belkaoui, A. (2004). Relationship between tax compliance internationally and selected determinants of tax morale. Journal of International Accounting, Auditing and Taxaxtion, 13, 135-143. http://dx.doi.org/10.1016/j.intaccaudtax.2004.09.001

Riahi-Belkaoui, A., \& Picur, R. (2000). Understanding fraud in the accounting environment. Manage Finance, 26(11), 33-41. http://dx.doi.org/10.1108/03074350010766972

Ross, M. (2001). Does oil hinder democracy? World Politics, 53(3). http://dx.doi.org/10.1353/wp.2001.0011

Saad, N. (2014). Tax Knowledge, Tax Complexity and Tax Compliance: Taxpayers' View. Procedia-Social and Behavioral Sciences, 109, 1069-1075. http://dx.doi.org/10.1016/j.sbspro.2013.12.590

Sheppard, B., Hartwick, J., \& Warshaw, P. (1988). The theory of reasoned action: A meta-analysis of past research with recommendations for modifications and future research. Journal of Consumer Research, 15, 325-343. http://dx.doi.org/10.1086/209170

Singh, S., \& Mbekomize, C. (2009). Factors contributing to tax evasion in Botswana: A Student Perspective. International Journal of Fianance and Policy Analyst, 2(1), 31-46.

Slemrod, J. (1985). An Empirical Test for tax evasion. The review of Economics and Statistics, 67(2), 232-238. http://dx.doi.org/10.2307/1924722

Triandis, H. C. (1995). Individualism and collectivism. BouldeR, CO: Westview Press.

Trivedi, V., Shehata, M., \& Mestelman, S. (2005). Attitudes, Incentives, and Tax Compliance. Canadian Tax Journal, 53(1), 29-61.

Zou, S. (1998). The determinants of export performance: A review of the empirical literature between 1987 and 1997. International Marketing Review, 15(5), 333-356. http://dx.doi.org/10.1108/02651339810236290

\section{Copyrights}

Copyright for this article is retained by the author(s), with first publication rights granted to the journal.

This is an open-access article distributed under the terms and conditions of the Creative Commons Attribution license (http://creativecommons.org/licenses/by/3.0/). 